\title{
A Basic Study on Development of Movable Light-Shelf System with a built-in PV
}

\author{
Min-seok Kim ${ }^{1}$, Daun $\mathrm{Choo}^{2}$, Yena $\mathrm{Yeo}^{3}$, and Heangwoo Lee ${ }^{4 *}$ \\ Interior design, College of Design, Sangmyung University, Cheonan-si, \\ Chungcheongnam-do, South Korea

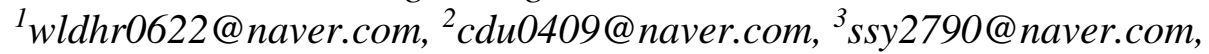 \\ 42hw@smu.ac.kr
}

\begin{abstract}
The constant increase of energy consumption in the building sector is causing many problems such as global warming. In particular, as the consumption of lighting energy is second to only cooling and heating, a wide variety of research and technology development is being performed to resolve this problem. The light-shelf is a type of natural daylighting system that introduces outdoor natural light deep into the room, and various studies have been carried out in recognition of its efficiency. In particular, a previous study that combined a $P V$ with a light-shelf was significant in terms of producing energy through the light-shelf. However, the previous study introduced the case in which the integrated $P V$ and light-shelves attached the $P V$ to the reflector of the light-shelf. In this way, the light-shelf and the PV operated at the same angle, which resulted in low daylighting and concentration efficiency. Therefore, the purpose of this study is to propose a movable light-shelf system with a built-in PV which operates at independent angles. The conclusions are as follows. The light-shelf system with a built-in PV proposed in this study consists of a structure where the light-shelf is installed at the bottom with the PV on top. In particular, the upper section has a hole to allow natural light to flow into the light-shelf at the bottom for daylighting. In addition, we enhanced the effectiveness of this study by suggesting control measures to operate the light-shelf system with a built-in PV. However, this study has limitations as it did not evaluate the performance of the light-shelf system with a built-in PV. Therefore, additional studies need to be performed in the future to evaluate and verify the performance.
\end{abstract}

Keywords: Light-shelf, Photovoltaic, Daylighting, Energy saving

\section{Introduction}

According to a survey by the International Energy Agency (IEA) in 2001, the amount of lighting energy used in the building sector was high at $22 \%$, which led to the need for various research and technology development to reduce lighting energy. The light-shelf is a type of natural daylighting system that introduces outdoor natural light deep into the room, and various studies have been carried out in recognition of its efficiency. A recent study introduced the case in which a PV was attached to the reflector of the light-shelf to reduce building energy by daylighting and concentrating light [1]. However, this study attached the PV directly to the reflector of the light-shelf. This method enables the components to operate at the same angle,

Article history:

Received (April 13, 2019), Review Result (May 10, 2019), Accepted (June 6, 2019) 
which may be unsuitable for improving the daylighting and concentration efficiency. This is because the daylighting performance of the light-shelf reflects the light to introduce more natural light into the room. However, the angle of incidence of the PV should be vertical to increase the concentration efficiency. This acts as a setback for developing industries related to light-shelves integrated with a PV.

Therefore, the purpose of this study is to develop a new conceptual system that maximizes the daylighting and power generation efficiency by operating the light-shelf and PV at different angles.

\section{Consideration of light-shelf and PV technologies}

\subsection{Concept and research trends of light-shelf}

As shown in [Figure 1], the light-shelf is a typical natural daylighting system that reflects and introduces external natural light deep into the room. In addition, light-shelves are installed in windows and are effective in improving imbalanced interior illuminance by partially blocking natural light that is directly introduced from the outside. In this respect, a wide variety of research and technology development related to light-shelves is being performed in recognition of its effectiveness in reducing lighting energy and improving the light environment. The angle, height, width, and reflectivity are variables that determine the daylighting performance of the light-shelf [2][3][4][5]. And, as shown in [Figure 2], the angle of the lightshelf is an important index that determines the daylighting performance of the light-shelf because it is easy to control the amount of natural light entering the room [6].

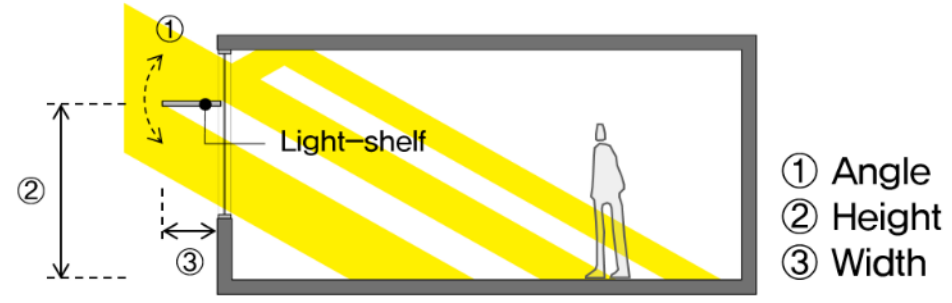

Figure 1. Concept and variables of the light-shelf

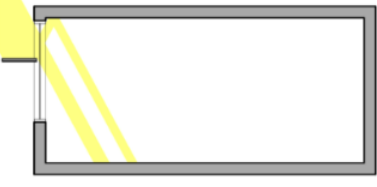

a) Light-shelf $0^{\circ}$

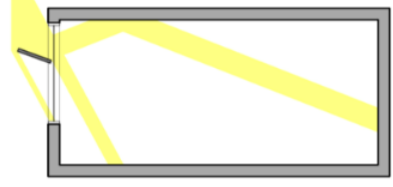

c) Light-shelf $20^{\circ}$

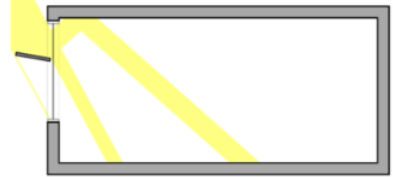

b) Light-shelf $10^{\circ}$

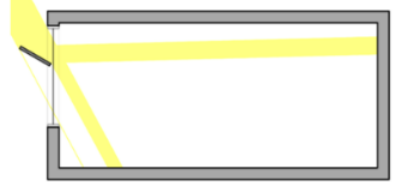

c) Light-shelf $30^{\circ}$

Figure 2. Diagrams of light inflow process at different angles of the light-shelf 
As shown in [Table 1], previous studies related to light-shelves integrated various envelope and IT technologies to maximize daylighting performance and reduce lighting energy $[1][3][4][5][6][7][8][9][10][11]$. In particular, previous studies that attached the PV to the reflector of movable light-shelves were significant in terms of producing energy through the PV [2][9]. However, such studies [1] attached the PV in front of the reflector of the light-shelf which eventually interferes with the role of the light-shelf as a daylighting device. Other studies [11] were performed by attaching the PV to a portion of the reflector to improve these issues. However, these cases were also considered to be unsuitable for efficiently reducing energy because the optimal angles to improve the daylighting performance of the light-shelf and to increase the PV power generation efficiency were different.

Table 1. Research trends related to light-shelf

\begin{tabular}{|c|c|c|}
\hline $\begin{array}{c}\text { Author } \\
\text { (publication year) }\end{array}$ & Research purpose & PV application \\
\hline $\begin{array}{l}\text { S. R. Kim et al. } \\
\text { (2017) [3] }\end{array}$ & $\begin{array}{l}\text { To develop a movable light-shelf technology to secure } \\
\text { daylighting performance and prospect rights }\end{array}$ & Unapplied \\
\hline $\begin{array}{l}\text { Y. S. Cho et al. } \\
\text { (2004) [4] }\end{array}$ & $\begin{array}{c}\text { To derive optimal light-shelf variables considering external } \\
\text { environment factors }\end{array}$ & Unapplied \\
\hline $\begin{array}{l}\text { H. W. Lee et al. } \\
\text { (2013) [5] }\end{array}$ & $\begin{array}{l}\text { To derive optimum light-shelf dimensions according to the } \\
\text { size of indoor space }\end{array}$ & Unapplied \\
\hline $\begin{array}{l}\text { G. M. Jeon et al. } \\
\text { (2016) [6] }\end{array}$ & $\begin{array}{l}\text { To derive optimum light-shelf dimensions to reduce cooling, } \\
\text { heating, and lighting energy }\end{array}$ & Unapplied \\
\hline $\begin{array}{l}\text { J. Y. Cho et al. } \\
\text { (2013) [7] }\end{array}$ & $\begin{array}{l}\text { To derive optimum light-shelf dimensions to improve the } \\
\text { daylighting performance in general hospitals }\end{array}$ & Unapplied \\
\hline $\begin{array}{l}\text { H. W. Lee et al. } \\
\text { (2014) [8] }\end{array}$ & $\begin{array}{l}\text { To derive optimum light-shelf dimensions according to the } \\
\text { type of indoor space }\end{array}$ & Unapplied \\
\hline $\begin{array}{l}\text { B. I. Park et al. } \\
\text { (2008) [9] }\end{array}$ & $\begin{array}{l}\text { To derive the optimal variables of the light-shelf to improve } \\
\text { the daylighting performance in the work space }\end{array}$ & Unapplied \\
\hline $\begin{array}{l}\text { W. R. Chea et al. } \\
\text { (2014) [10] }\end{array}$ & $\begin{array}{l}\text { To derive optimum light-shelf dimensions of a mixed-type } \\
\text { light-shelf to improve the daylighting performance }\end{array}$ & Unapplied \\
\hline $\begin{array}{l}\text { H. Park at al. } \\
\text { (2012) [1] }\end{array}$ & $\begin{array}{c}\text { To evaluate the performance according to the installation angle } \\
\text { of a PV-integrated light-shelf }\end{array}$ & $\begin{array}{l}\text { Attached to the front of } \\
\text { the light-shelf reflector }\end{array}$ \\
\hline $\begin{array}{l}\text { J. M. Kim et al. } \\
\text { (2018) [11] }\end{array}$ & $\begin{array}{l}\text { To evaluate the performance of the light-shelf according to the } \\
\text { PV attachment area }\end{array}$ & $\begin{array}{l}\text { Attached to part of the } \\
\text { light-shelf reflector }\end{array}$ \\
\hline
\end{tabular}

\subsection{PV concept and control technology}

Solar energy is largely divided into light energy and thermal energy, and PV is the conversion of light into electricity using semiconducting materials. As shown in [Figure 3], PV generates power by emitting light on semiconducting materials to generate electrons and holes forming a (+) electrode and a (-) electrode, and an electrical current flows when the electrodes are connected to an external circuit. This is the basic principle in which solar cells convert light into electricity. In this regard, the sunlight should be vertically incident on the PV to increase the power generation efficiency of the PV. Therefore, the PV needs to be controlled according to the solar altitude and the azimuth angle [11]. 


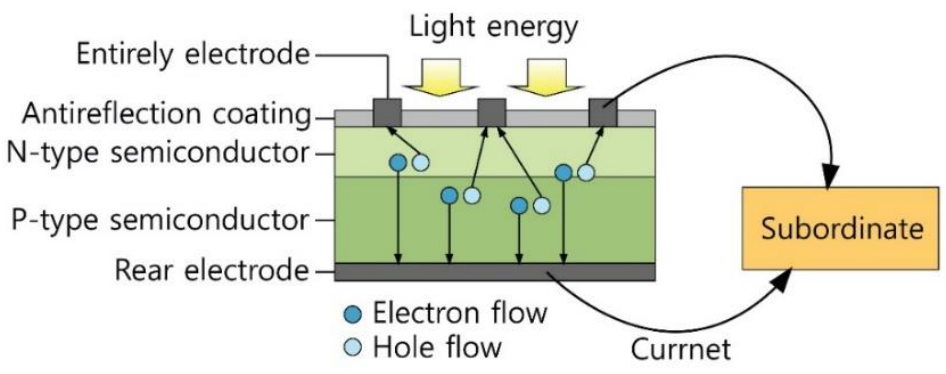

Figure 3. PV concept and power generation principle

\section{Suggestion of movable light-shelf system with a built-in PV}

As shown in [Figure 4] and [Figure 5], this study suggests a new natural daylighting and concentration system which integrates a light-shelf and PV. The details are as follows. First, the movable light-shelf system with a built-in PV proposed in this study consists of a structure where the light-shelf is installed at the bottom with the PV on top. In particular, the upper section has a hole to allow natural light to flow into the light-shelf at the bottom for daylighting. Second, the angle of the light-shelf can be controlled, and the PV is connected to an axis that moves along the window rail, which allows independent angle control regardless of the angle of the light-shelf. Third, the control method of the movable light-shelf system with a built-in PV in this study is as follows. First, control the angle of the light-shelf. This study does not describe how to control the angle of a light-shelf because it has been already covered by previous studies [4][5][6][7][8][9]. Control the angle of the PV after adjusting the light-shelf, and control the angle to maximize PV power generation. As mentioned above, make sure that the PV is vertical to increase the PV power generation efficiency. This method of control will upgrade the contents of previous studies [1][11]by maximizing the daylighting and concentration efficiency of the movable light-shelf system with a built-in PV.

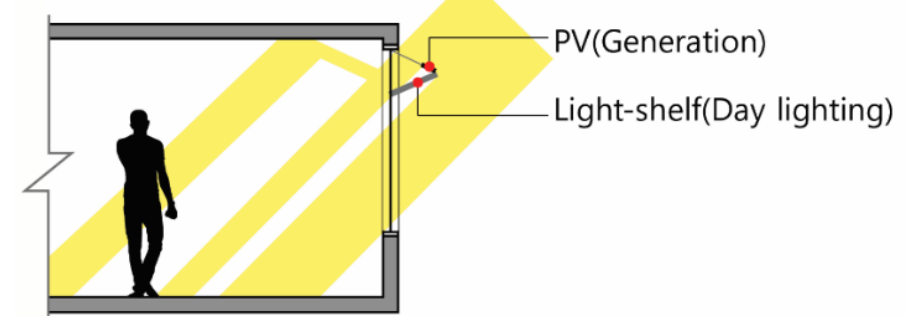

Figure 4. Concept and principle of the movable light-shelf system with a built-in PV

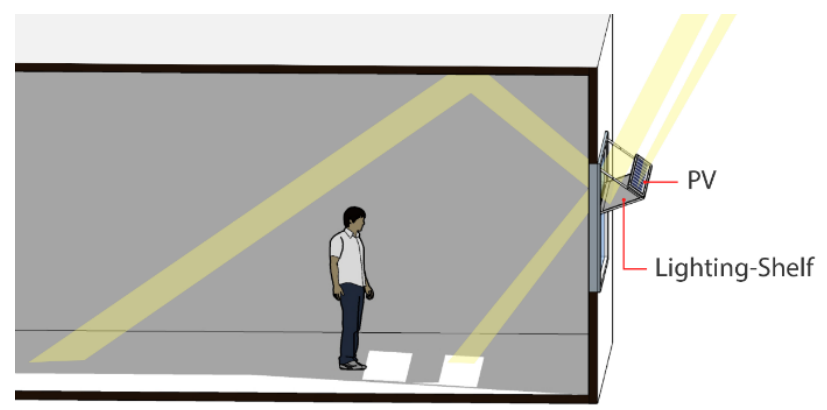

Figure 5. Daylighting and concentration of the movable light-shelf system with a built-in PV 


\section{Conclusion}

This study proposed a movable light-shelf system with a built-in PV to reduce building energy and the conclusions are as follows. First, the movable light-shelf system with a built-in PV proposed in this study consists of a structure where the light-shelf is installed at the bottom with the PV on top. In particular, the upper section has a hole to allow natural light to flow into the light-shelf at the bottom for daylighting. Second, the movable light-shelf system with a built-in PV can be controlled at different angles in order to improve the daylighting and concentration efficiency. For this purpose, we added an independent moving component to control the angle of the PV in addition to the conventional light-shelf control. Third, this study is effective in terms of establishing basic data for related fields by proposing a movable lightshelf system with a built-in PV to reduce building energy. However, the limitation of this study is that no performance evaluation was performed to verify this. Therefore, additional studies in the future will include a performance evaluation to address this limitation.

\section{Acknowledgements}

This research was supported by a National Research Foundation of Korea Grant (2018R1C1B4A01018660) funded by the Korean Government.

\section{References}

[1] H. Park, Y. G. Chung, and J. T. Kim, "The performance evaluation of photovoltaic-integrated light shelf systems,” KIEAE Journal, vol.12, no.6, pp.129-134, (2012)

[2] H. W. Lee, K. E. Rogers, J. H. Seo, and Y. S. Kim, “A study on lighting performance evaluation of light-shelf using crystal face," Korean Journal of Air-Conditioning and Refrigeration Engineering, vol.27, no.8, pp.395401, (2015) DOI: 10.6110/KJACR.2015.27.8.395

[3] S. R. Kim, H. W. Lee, J. H. Seo, and Y. S. Kim, "Research of the development of a height-adjustable lightshelf based on an open and closed concept," KIEAE Journal, vol.17, no.3, pp.83-90, (2017) DOI: 10.12813/kieae.2017.17.3.083

[4] Y. S. Cho, B. S. Kim, and J. S. Lee, "Analysis on the indoor daylight performance and optimum size selection of a light shelf using lightscape," Journal of the Architectural Institute of Korea Planning \& Design, vol.20, no.6, (2004)

[5] H. W. Lee, D. S. Kim, and Y. S. Kim, "Simulation study on the performance evaluation of light-shelf focused on the depth of space and the dimensions and angles of light-shelf," Journal of the Architectural Institute of Korea Planning \& Design, vol.29, no.3, pp.335-344, (2013) DOI: 10.5659/JAIK_PD.2013.29.3.335

[6] G. M. Jeon, H. W. Lee, J. H. Seo, and Y. S. Kim, "Performance evaluation of light-shelf based on light environment and air conditioner environment," KIEAE Journal, vol.16, no.5, pp.47-55, (2016) DOI: 10.12813/kieae.2016.16.5.047

[7] J. Y. Cho and H. W. Lee, "A study on the effect of inflow daylight according to the installation method of controlling light shelf and blind in the room of general hospital," KIEAE Journal, vol.13, no.4, pp.3-10, (2013) DOI: 10.12813/kieae.2013.13.4.003

[8] H. W. Lee, Y. S. Kim, J. H. Seo, and D. S. Kim, "Simulation study on the performance evaluation of lightshelf according to geometric shape of ceiling," Korean Journal of Air-Conditioning and Refrigeration Engineering, vol.26, no.4, pp.181-192, (2014) DOI: 10.6110/KJACR.2014.26.4.181

[9] B. I. Park, I. H. Yang, and M. H. Na, "An analysis of daylighting performance of light shelf in office building" Journal of the Korean Institute of Illuminating and Electrical Installation Engineers, vol.22, no.8, pp.1-11, (2008) DOI: 10.5207/JIEIE.2008.22.8.001 
[10] W. R. Chea, H. W. Lee, J. H. Seo, and Y. S. Kim, "Evaluation of lighting performance of mixed type lightshelf in residential space according to angular variations," Korean Journal of Air-Conditioning and Refrigeration Engineering, vol.26, no.9, pp.424-433, (2014) DOI: 10.6110/KJACR.2014.26.9.424

[11] J. M. Kim, H. W. Lee, J. H. Seo, and Y. S. Kim, "A preliminary study on lighting performance and energy savings of a PV-attached light shelf," Korean Journal of Air-Conditioning and Refrigeration Engineering, vol.30, no.8, (2018)

\section{Authors}

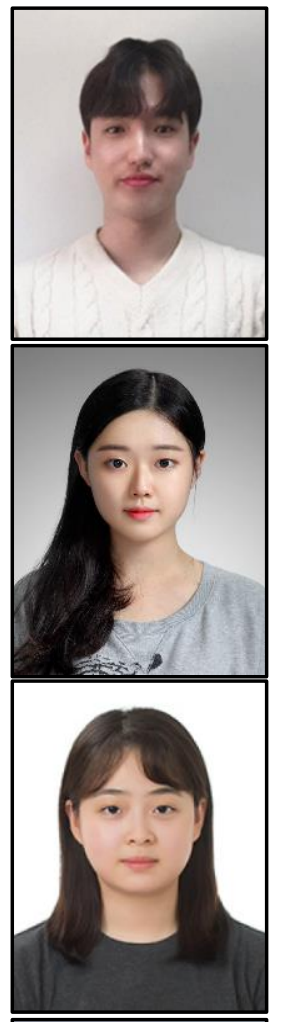

Min-seok Kim

Sangmyung university, Undergraduate course.

\section{Daun Choo}

Sangmyung university, Undergraduate course.

\section{Yena Yeo}

Sangmyung university, Undergraduate course.

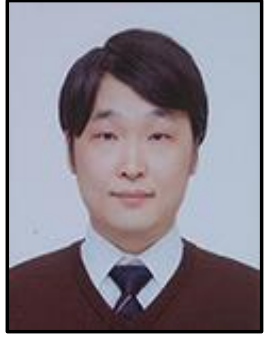

\section{Heangwoo Lee (Corresponding author)}

Sangmyung university, Assistant Professor. 